\title{
The Study on Fish Fauna of Singaraya Reservoir, Siddipet District Telangana
}

\author{
T.JAGADEESHWARA CHARI*, DR.A.V.RAJASHEKHAR \\ Department of Fisheries(PG), Government Degree \&PGccollege Siddipet,Telangana State
}

*Corresponding Author: Dr.T.Jagadeeshwara chari, Department of fisheries (PG), Government Degree \& $P G$ college Siddipet

\begin{abstract}
Telanagana has abundant aquatic resources in the form of rural village tanks. They are multipurpose tanks used for cloth washing, cattle caring and agriculture. Normally, local fishermen form a cooperative society and culture fish in these tanks for their livelihood.The preset study fish fauna of Singaraya reservoir was carried out on June 2019-May 2020.The samples were collected with the help of local fisherman. The results of present study confirmed the occurrence of 33 species belonging to 6 orders. The order Cypriniformes 15 species, Siluriformes 8 species, Osteoglossiformes 2 species, Channiformes 3 species, Perciformes 4 species, Anthrniformes 1 species were identified. Order wise percentage composition is Cypriniformes (46\%), Siluroformes (24\%), Perciformes (12\%), Channiformes (9\%), Anthrniformes (3\%) Thus the Lake was good potential of fish fauna.
\end{abstract}

Keywords: Siddipet district,Singaraya reservoir, Fish Fauna,fisherman

\section{INTRODUCTION}

Pisces are the major group of vertebrates which shows an enormous diversity in shape, size, biology and habitat (Bobdey, 2014).The aquatic ecosystem is important and it has large number of economically fish which is an important source of food. Fishes are the important vertebrate group of animal's world contributing to the biodiversity of animals. Primarily fishes are used as a food source. Many vital vitamins and fatty acids are found in fishes so sometimes it is referred by doctors as a food source. Freshwater resources are used for various purposes, like agricultural, industrial, household, recreational, environmental activities etc. Reservoirs and lakes are the main resources exploited for inland fisheries and understanding the fish faunal diversity is a major aspect for its development and the sustainability management. Lakes in India support rich variety of fish species, which intern support the commercial exploitation of the fisheries potential (Krishna and Piska, 2006). Ichthyo diversity refers to variety of fish species; depending on context and scale, it could refer to alleles or genotypes within fish population to species of life forms within a fish community and to species or life forms within a fish community and to species of life forms across aqua regimes (Burton et al., 1992).India is one of the mega biodiversity countries in the world and occupies the ninth position in terms of freshwater mega biodiversity (Shinde et al., 2009). There are 450 families of freshwater fishes globally, out of which 40 families are represented from India ( Keshava et al.,2013).Maharashtra is rich in freshwater reservoir fish diversity(Pawara et al., 2014).Studies on taxonomy (Ichthyofaunal diversity) have been of immense interest to researchers of all times(Hamilton,1822;Day,1878 and Menon,1992).However ,there are still a large number of habitats/regions for which the Ichthyofaunal diversity is still to be reported. The present investigation was under taken to study the aquatic vertebrate animals with reference to fishes from Singaraya reservoir.

\section{Materials AND Metods}

The present study was carried out on in fresh water lake of kurella is located $18^{\circ} 9^{\prime} 25^{\prime \prime} \mathrm{N} \quad 79^{\circ} 2^{\prime} 34^{\prime \prime} \mathrm{E}$ village in Siddipet district, Telangana. Fishes were collected from different localities for the period of one year from June 2019-May 2020 with the help of local fishermen using different types of nets namely gill nets, cast nets and drag nets. The collected fishes were preserved in 10\% formalin and identified with following work of Day (1878), Menon and Talwar (1972), Datta Munshi and Srivastava (1968), Talwar and Jhingran, (1991) and Jayaram, (2010). 


\section{RESULTS AND DISCUSSION}

In the present study, 33 species of 18 different genera 12 families and 6 orders were recorded from Singaraya reservoir. Cypriniformes 15 species i.e. Catla catla, Cirrhinus mrigala, Cirrhinus reba, Labeo calbasu,Labeo rohita,Labeo potial,Labeo gonitu,Cyprinus carpio carpio, Punctius chola, Punctius titius, Punctius sophore, Punctius sarana sarana, Amplypharygodon microlepis, Salmostoma bacaila, Lepidocephalius guntea. Then the order Siluriformes consists of 8 species i.e. Mystus bleeker, Mystus cavasius, Mystus vittatus, Wallago attu, Ompok bimaculatus, Ompokpabda, Clarius batracus, Heteropneustues fossils. Order Osteoglossiformes consists of 2 species i.e. Notopterus Notopterus, Notopterus chitala.Order Channiformes consists of 3 species i.e. Channa punctatus, Channa striatus, Channa orientalis. Order Perciformes consists of 4 species i.e. Glosobius giuris giuris, Anabas testudineus, Mastacembelus armatus, Mastacembelus panclus. Order Anthrniformes consists of 1 species i.e. Xenentodon cancilla (Table-1).Order wise percentage composition is Cypriniformes (46\%), Siluroformes (24\%), Perciformes (12\%), Channiformes (9\%), Anthrniformes (3\%) (Table-2, Graph1).In these reported fishes, Cypriniformes was more dominant. Many researchers have reported the strong dominance of Cyprinidae family. Khedkar and Gynanth (2005) reported 37 species in Issapur Reservoir District Yeotmal, Maharastra State India., Sharma (2008) reported 87 species in Issapur dam in district Yavatmal, Laxmappa and Ravindar Rao (2015) , Thirupathaiah M, Samatha Ch,Sammaiah.Ch(2014) reported 25 species in Diversity and Conservation Status of Fish Fauna in Freshwater Lake of Kamalapur, Krimnagar District , Nagma et al (2013) reported 18 species in study fresh water fish fauna of district Bijnour in Uttar Pradesh, Surender Reddy. K, Balabrishna. D, Swarna Latha. U, Ravinder Reddy (2015) Renuka Yellamma Lake, Peddapally, Karimnagar District, Srikanth. K, Ramu. G, Benarjee. G (2009) reported 31 species in Ramappa Lake Warangal, A.P, Rama Rao. K (2014) reported 23 species in Ichthyofaunal bio diversity in the lower Manair Dam at Karimnagar district; Telangana State, India, Ahirrao (2014) reported 39 species in Bori dam at Tamaswadi, Parola Dist. Jalgaon, Pawar (2014) reported 42 species in Majalgaon reservoir from Beed district.

Table1. Showing Fish Fauna of Singaraya Reservoir District

\begin{tabular}{|c|c|c|c|c|}
\hline ORDER & FAMILY & GENUS & SPECIES & LOCAL NAME \\
\hline 1.Cypriniformes & Cyprinidae & $\begin{array}{c}\text { Catla } \\
\text { Cirrhinus } \\
\text { Labeo } \\
\\
\text { Cyprinus } \\
\text { Punctius } \\
\\
\text { Salmostoma } \\
\end{array}$ & $\begin{array}{l}\text { 1. Catla Catla } \\
\text { (Hamilton- } \\
\text { Buchanan, 1822) } \\
\text { 2.Cirrhinus mrigala } \\
\text { (Hamilton- } \\
\text { Buchanan,1822) } \\
\text { 3. Cirrhinus reba } \\
\text { (Hamilton- } \\
\text { Buchanan,1822) } \\
\text { 4.Labeo calbasu } \\
\text { (Hamilton- } \\
\text { Buchanan,1822) } \\
\text { 5.Labeo rohita } \\
\text { (Hamilton- } \\
\text { Buchanan,1822) } \\
\text { 6.Labeo } \\
\text { potail(Sykes, 1839) } \\
\text { 7.Labeo goniu } \\
\text { (Hamilton,1822) } \\
\text { 8.Cyprinus carpio } \\
\text { carpio (1758) } \\
\text { 9.Punctius chola } \\
\text { (Hamilton- } \\
\text { Buchanan,1822) } \\
\text { 10.Punctius titius } \\
\text { (Hamilton- } \\
\text { Buchanan,1822) } \\
\text { 11.Puctius sophore } \\
\text { (Hamilton- } \\
\text { Buchanan,1822) }\end{array}$ & $\begin{array}{c}\text { Botcha } \\
\text { Merige } \\
\text { Arju } \\
\text { Kakibocche } \\
\text { Rohu } \\
\text { Bocche } \\
\text { Kursi } \\
\text { Bangaarutheega } \\
\text { Parka } \\
\text { Budda parka } \\
\text { Parka } \\
\text { Kodipe } \\
\text { Chandamama }\end{array}$ \\
\hline
\end{tabular}


The Study on Fish Fauna of Singaraya Reservoir, Siddipet District Telangana

\begin{tabular}{|c|c|c|c|c|}
\hline & & & $\begin{array}{c}\text { 12.Punctius sarana } \\
\text { sarana (Hamilton- } \\
\text { Buchanan(1822) } \\
\text { 13.Amplypharygodon } \\
\text { microlepis } \\
\text { (Bleeker, 1854) } \\
\text { 14. Salmostoma bacaila } \\
\text { (Hamilton, 1822) }\end{array}$ & \\
\hline & Cobitidae & Lepidocephalus & $\begin{array}{c}\text { 15.Lepidocephalius } \\
\text { guntea (Bleeker,1822) }\end{array}$ & Ulshe \\
\hline \multirow[t]{4}{*}{ 2.Siluriformes } & Bagridae & Mystus & $\begin{array}{l}\text { 16. Mystus bleeker } \\
\text { (Day, 1877) } \\
\text { 17.Mystus cavasius } \\
\text { (Hamilton,1822) } \\
\text { 18.Mystus vittatus } \\
\text { (Bloch,1822) }\end{array}$ & $\begin{array}{c}\text { Jella } \\
\text { Guddi Jella } \\
\text { Erra Jella }\end{array}$ \\
\hline & Siluridae & $\begin{array}{l}\text { Wallago } \\
\text { Ompok }\end{array}$ & $\begin{array}{c}\text { 19. Wallago attu } \\
\text { (Schineider,1839) } \\
\text { 20.Ompok bimaculatus } \\
\text { (Bloch,1974) } \\
\text { 21.Ompok pabda } \\
\text { (Hamilton,1822) }\end{array}$ & $\begin{array}{c}\text { Waaluga } \\
\text { Buggadumma }\end{array}$ \\
\hline & Clarridae & Clarius & $\begin{array}{l}\text { 22.Clarius batracus } \\
\text { (Linnaeus, 1758) }\end{array}$ & Marphoo \\
\hline & $\begin{array}{c}\text { Heteropneustida } \\
\mathrm{e}\end{array}$ & Heteropneustes & $\begin{array}{l}\text { 23.Heteropneustues } \\
\text { fossils (Bloch,1794) }\end{array}$ & Inglikam \\
\hline $\begin{array}{l}\text { 3.Osteoglossifome } \\
\text { s }\end{array}$ & Notopteridae & Notopterus & $\begin{array}{c}\text { 24. Notopterus } \\
\text { Notopterus } \\
\text { (Pallas, } 1769) \\
\text { 25. Notopterus chitala } \\
\text { (Hamilton) }\end{array}$ & $\begin{array}{l}\text { Vollenka } \\
\text { Vollenka }\end{array}$ \\
\hline 4.Channiformes & Channidae & Channa & $\begin{array}{c}\text { 26.Channa punctatus } \\
\text { (Bloch,Day-1878) } \\
\text { 27.Channa } \\
\text { striatus(1793) } \\
\text { 28.Channa orientalis } \\
\text { (Bloch\&Schneider, } 1801 \\
\text { ) }\end{array}$ & $\begin{array}{c}\text { Mottapilla } \\
\text { Korramatta/Murre } \\
1 \\
\text { Malapankidi }\end{array}$ \\
\hline \multirow[t]{3}{*}{ 5.Perciformes } & Gobidae & Glosogobius & $\begin{array}{c}\text { 29.Glosobius giuris } \\
\text { giuris (Hamilton,1822) }\end{array}$ & Ushkedhanthi \\
\hline & Anabantidae & Anabas & $\begin{array}{l}\text { 30.Anabas testudineus } \\
\text { (Bloch, 1792) }\end{array}$ & Burka \\
\hline & $\begin{array}{c}\text { Mastacembelida } \\
\mathrm{e}\end{array}$ & Mastaembelus & $\begin{array}{c}\text { 31.Mastacembelus } \\
\text { armatus } \\
\text { (Lecepede, } 1800) \\
\text { 32.Mastacembelus } \\
\text { panclus } \\
\text { (Lecepede, } 1800) \\
\end{array}$ & $\begin{array}{c}\text { Paapera } \\
\text { Chinni paapera }\end{array}$ \\
\hline 6.Anthrniformes & Belonidae & Xenontodon & $\begin{array}{l}\text { 33.Xenentodon cancilla } \\
\text { (Hamilton, 1822) }\end{array}$ & Nayanikuntha \\
\hline
\end{tabular}

Table2. Order wise fish species in Singaraya Reservoir

\begin{tabular}{|c|c|c|}
\hline S.NO & Order & Number of Fish Species \\
\hline 1. & Cypriniformes & 15 \\
\hline 2. & Siluriformes & 8 \\
\hline 3. & Osteoglossiformes & 2 \\
\hline 4. & Channiformes & 3 \\
\hline $\mathbf{5 .}$ & Perciformes & 1 \\
\hline 6. & Anthrniformes & $\mathbf{3 3}$ \\
\hline Total & $\mathbf{6}$ & \\
\hline
\end{tabular}




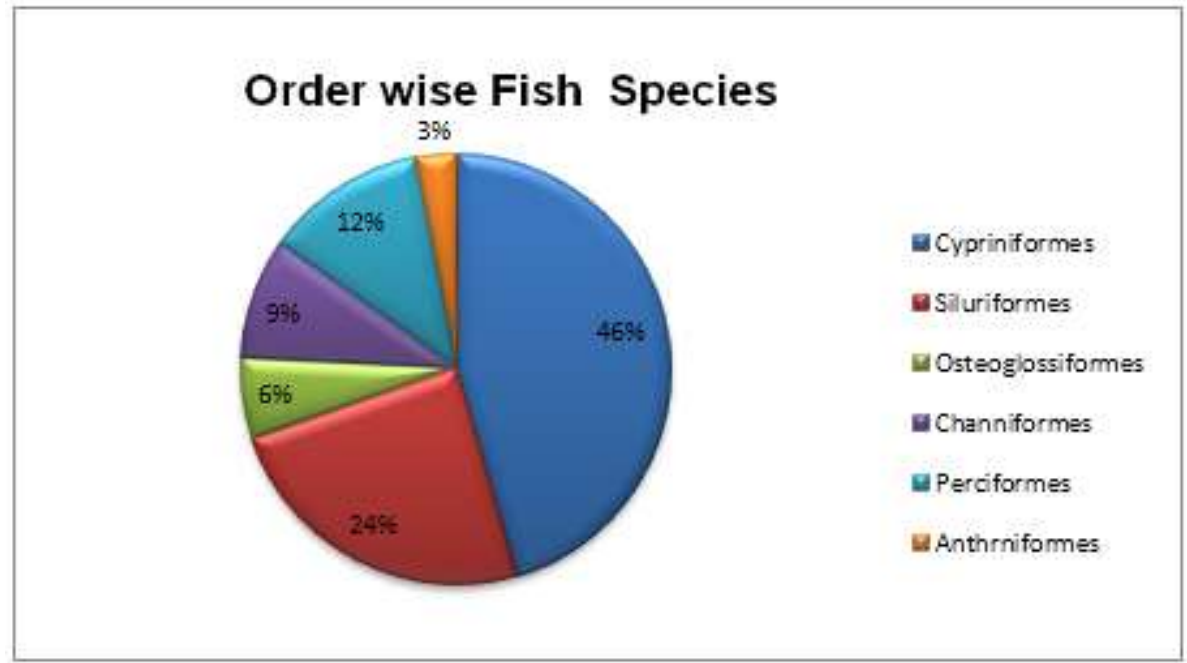

Graph1. Order wise fish species Percentage in Singaraya Reservoir

Table3. Family wise fish species in Singaraya Reservoir

\begin{tabular}{|c|c|c|c|}
\hline S.NO & Families & $\begin{array}{c}\text { No. of Fish } \\
\text { Species }\end{array}$ & Percentage \\
\hline 1 & Cyprinidae & 14 & $43 \%$ \\
\hline 2 & Cobitidae & 1 & $3 \%$ \\
\hline 3 & Bagridae & 3 & $9 \%$ \\
\hline 4 & Siluridae & 3 & $3 \%$ \\
\hline 5 & Clarridae & 1 & $3 \%$ \\
\hline 6 & Heteropneustidae & 1 & $6 \%$ \\
\hline 7 & Notopteridae & 2 & $9 \%$ \\
\hline 8 & Channidae & 3 & $3 \%$ \\
\hline 10 & Gobidae & 1 & $3 \%$ \\
\hline 11 & Anabantidae & 1 & $6 \%$ \\
\hline 12 & Mastacembelidae & 2 & $3 \%$ \\
\hline
\end{tabular}

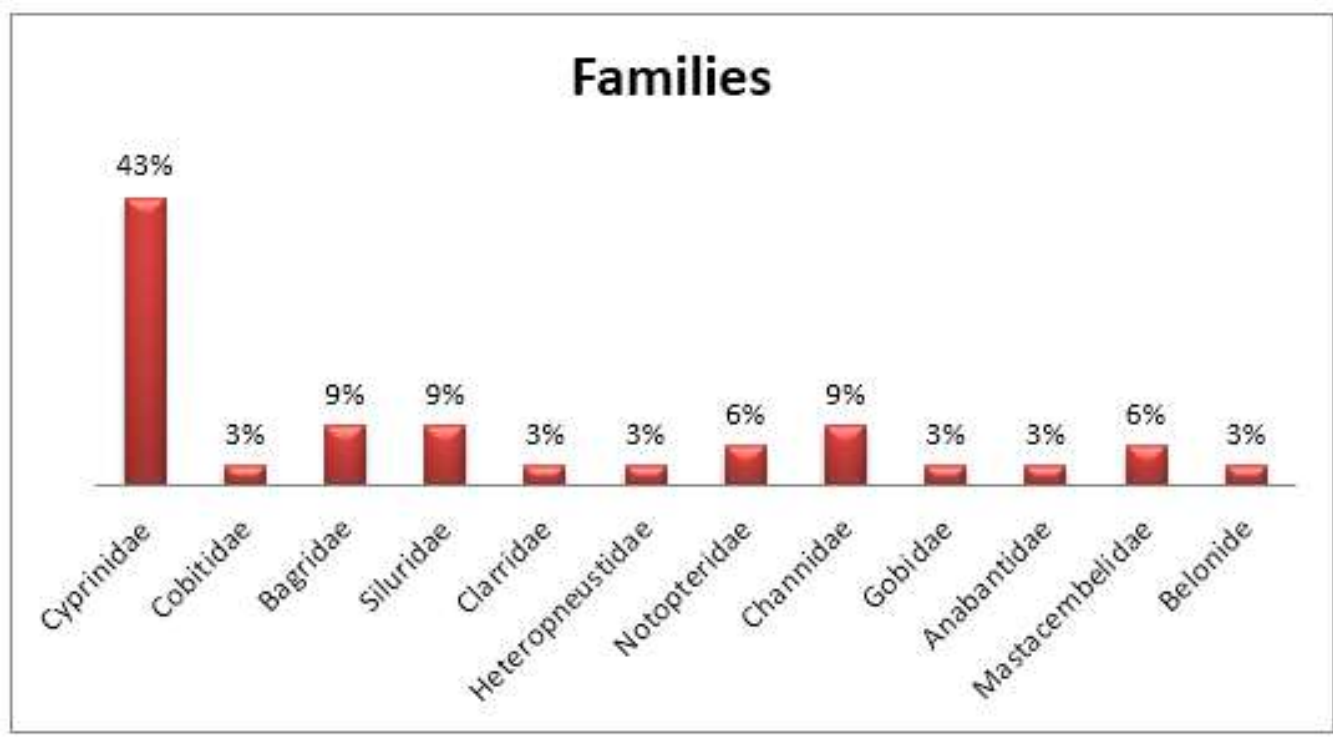

Chart1. Family wise fish species Percentage in Singaraya Reservoir

\section{Conclusion}

The reservoir is under control of primary fisherman society for fish culture. The present study is the first ever documentation of ichthyofauna in the Singaraya Reservoir of Siddipet district in Telangana state. We explained the people who are depended fishermen families on this reservoir to prevent by following a fishing holiday of about three months during the breeding season from July to September 
in order to allow the proper growth of fishes and mesh regulation in fishing is also an important factor. Creating mass awareness is need to save the threatened fish fauna of this reservoir, also fishermen and protecting divers fish resources. Sustainable fish production by taking appropriate steps for sustaining diversity is necessary to conserve these resources.

\section{REFERENCES}

[1] Burton P J, Balisky AE, Coward LP, Cumming S G and Kneshwaw D D(1992),"The value of Managing Biodiversity", The Forestry Chronicle,Vol.68,No.2,pp.225-237.

[2] Bobdey, A. D. Ichthyodiversity and Conservation Aspects in a Lake and River ecosystem in Bhandara District of Maharastra, India: A Comprehensive study of surface water bodies. Interdisciplinary Research Journal, 4 (2):103-112(2014).

[3] Day F (1878), The Fishes of India, Being A Natural History of the Fishes Known to Inhabit the Seas and Fresh Waters of India, Burma and Ceylon, Vol. I and II. Ceylon text and atlas in 4 pts., London.

[4] Datta Munshi and Srivastava, M.P., Natural history of fishes and systematic of freshwater fishes of India. Narendra publishing House, Delhi (1968).

[5] Hamilton Buchanan (1822).An Account of the Fishes Found in the River Ganges and its Branches. Vol. IVII. Printed for Archibald constable and company, Edinburgh and Hurst, Robinson and Co-90, Cheapside London, p. 405.

[6] Jayaram K C (2010),The Freshwater Fishes of the Indian Region, Second Edition. Narendra Publishing House, Delhi,P.616.

[7] Keshava, J. V., P.S. Ananthan and Aasha Landge Fish diversity and productivity of Isapur Reservoir, Maharashtra state. International Journal of Biomedical and Advance Research, 4(12):865-867(2013).

[8] Khedkar G D and Gynanth G (2005), Biodiversity and Distribution of the Fishes from the Back Waters of Issapur Reservoir District Yeotmal, Maharashtra State India. Trends in Life Science (India), Vol. 20,No.2,p.117.

[9] Krishna, M and Piska, R.S. Ichthyofaunal diversity in secret lake Durgamcheruvu, Rangareddy district, Andhra Pradesh, India. J. Aqua.Biol., Vol. 22(1):77-79(2006).

[10] Laxmappa B,Ravinder Rao B,Venkata Siva Narayana D.Studies on Ichthyofaunal diversity of Krishna River in Mahabubnagar District, Telangana, India, International Journal of Fisheris and Aquatic Studis.2015;2(5):99-104.

[11] Menon A G K (1992), The Fauna of India and Adjacent Countries, Pisces, Vol.4, Teleostei Cobitoidea, Part2 Cobitoidea. Zoological Survey of India, Kolkata,p. 113.

[12] RamuG, Ravindre B, Narasimha Ramulu K, Benarjee G. The Fish Fauna of Mylaram Reservoir in Warangal District, Andhra Pradesh Aquaculture.2009;10(2):313-316.

[13] Shinde S E, Paithane R Y, Bhandare and Sonawane D L(2009),'”chthyofaunal diversity of Harsool Savangi Dam district Aurangabad (M.S) India", World J. Fresh Mar.Sci.,1,Vol.3,pp.141-143.

[14] Surender Reddy K, Balakrishna D, Swarna Latha U, Ravinder Reddy T. Ecological Studies of Renuka Yellamma Lake, Peddapally, Karimnagar District, Telangana, Indian Journal of Biology.2015;2(1):13-17.

[15] Talwar, P. K ND A.G. Jhingran. Inland fishes of India and adjacent countries. Vol. I and II. Oxford \& IBH Publ. Co. Pvt. Ltd., New Delhi (1991).

[16] Thirupathaiah M, Samatha Ch, Sammaiah Ch. Diversity and Conservation Status of Fish Fauna in Freshwater Lake of Kamalapur. Karimnagar District, Telangana, India, IOSR Journal of Environmental Science, Toxicology and Food Technology.2014;8(5):9-24.

Citation: T.JAGADEESHWARA CHARI, DR.A.V.RAJASHEKHAR, "The Study on Fish Fauna of Singaraya Reservoir, Siddipet District Telangana”, International Journal of Innovative Studies in Aquatic Biology and Fisheries, 6(4), pp. 21-25. DOI: https:// doi.org/10.20431/2454-7670.0604004

Copyright: () 2020 Authors, this is an open-access article distributed under the terms of the Creative Commons Attribution License, which permits unrestricted use, distribution, and reproduction in any medium, provided the original author and source are credited. 